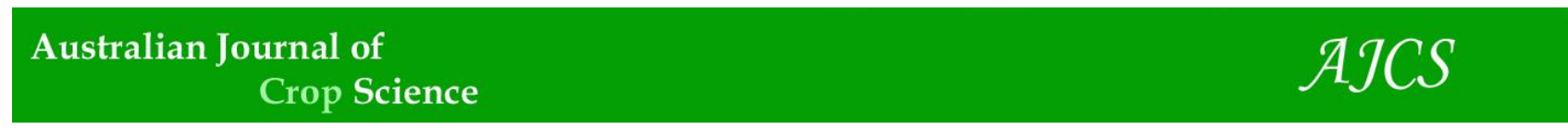

AJCS 12(06):849-854 (2018)

ISSN:1835-2707

doi: 10.21475/ajcs.18.12.06.PNE524

\title{
Response of Cratylia argentea (Desvaux) O. Kuntzeto inoculation with Rhizobium sp. and Bradyrhizobium sp. strains
}

Eduardo P. L. Mattar ${ }^{1 *}$, Tiago T. V. Barros ${ }^{2}$, Bruno P. Brasileiro ${ }^{3}$, Edson M. Mattielo ${ }^{4}$, Marcia R. R. Coelho ${ }^{5}$, Guilherme F. V. Gama², Denise C. F. dos S. Dias ${ }^{2}$

${ }^{1}$ Multidisciplinary Center, Federal University of Acre, Road Canela Fina, s / No, Cruzeiro do Sul, Acre, Brazil

${ }^{2}$ Department of Plant Production, Federal University of Viçosa, Avenue Peter Henry Rolfs, $s$ / $N^{\circ}$, Viçosa, Minas

Gerais, Brazil

${ }^{3}$ Department of Plant Production, Federal University of Paraná, Road Funcionários, 1540, Curitiba, Paraná, Brazil

${ }^{4}$ Department of Soil and Plant Nutrition, Federal University of Viçosa, Avenue Peter Henry Rolfs, $\mathbf{s} / \mathbf{N}^{\circ}$, Viçosa,

Minas Gerais, Brazil

${ }^{5}$ Embrapa Agrobiologia, Highway BR-465, Km 7, s / Nº, Seropédica, Rio de Janeiro, Brazil

"Corresponding author: eduardo@ufac.br

\begin{abstract}
Cratylia argentea is a neotropical leguminous shrub that exhibits symbiosis with nitrogen (N) fixing bacteria and high levels of protein. Thus, it has potential for animal feed and green manure. In spite of its potential, few cultivars are registered for the species and there is little information in regard to its interaction with $\mathrm{N}$-fixing microorganisms. The aim of this study was to evaluate the effect of inoculation with rhizobium strains on the growth and concentration of $\mathrm{N}$ in Cratylia argentea. Seeds were inoculated with two strains of Rhizobium sp.,CR 33 (BR10243) and CR42 (BR10244), and four strains of Bradyrhizobium sp., CR52 (BR10257), CPACB10, SEMIA 6464 (BR3262), and SEMIA 6462 (BR3267), and sown in pots filled with sand and vermiculite in a greenhouse. After 150 days we evaluated the number of nodules, shoot and nodules dry matter, total nitrogen and crude protein contents for the shoots. The plants inoculated with CR 52 exhibited nodulation, with nodular efficiency of 0.189 and relative efficiency of $66.14 \%$; it is possible to observe the effect of nodulation as of 85 days after sowing. Based on the obtained results it was identified the strain that showed symbiosis with $C$. argentea and presents potential to be used as a commercial inoculant.
\end{abstract}

Keywords: nodulation, forage, leguminous plant, biological $\mathrm{N}$ fixation, root nodule bacteria, green manure.

Abbreviations: WI_Treatments with inoculant and without nitrogen fertilization, NI_Treatments without inoculant and without nitrogen fertilization, WN_Treatments without inoculant and with nitrogen fertilization, CV_Coefficient of variation, SDM_Shoot dry matter, NN_Number of nodules, NDM_Nodule dry matter , N_N contents, CP_Crude protein contents.

Introduction

Cratylia is a neotropical leguminous genus found mainly in Brazil, Peru, Bolivia, and the northeast of Argentina (Lascano et al., 2002). Cratyliaargentea is the most widespread species (Queiroz 1991; Lascano et al., 2002), which occurs in Brazil in different environments, such as the Cerrado (Brazilian tropical savanna), Amazon rainforest, and Caatinga (xeric shrubland) (Queiroz, 1991).

C. argentea is a shrub that branches out at the base of the stem, reaching up to 3 meters height and has high capacity for producing new shoots, resulting from vigorous root growth (Lascano et al., 002). This ability is also manifested under water deficit (Argel and Lascano, 2002; Castilloet al., 2007). The species tolerates nutrient deficiency and acidic soils and also produces abundant seeds with excellent germination, presenting a strong regrowth capacity (Reyes et al., 2007; Alpala et al., 2010). Also it is able to maintain its leaves even in prolonged periods of drought (Castillo et al., 2007).
Although it is not widespread in Brazil, C. argentea shows potential for use in tropical crop and livestock operations, especially as a source of protein for animal feed and in green manure. Studies show the use of leaf silage as a supplement for milk cows on family farms (Argel et al., 2000) and in pig feed (Sarria and Martens 2013). It has low tannin content and its protein values (18\%to $30 \%$ crude protein) are comparable to those of Gliricidia sepium (Jacq.) Kunthex Walp.and of Leucaena leucocephala (Lam.) de Wit, species commonly used as forages (Cook et al., 2005).

It is recommended both for forage accumulation and for pasture, in intercropping with grasses. In this perspective, it is a promising species, considering that tropical leguminous forage plants are able to meet the requirements for balancing the $\mathrm{N}$ cycle in managed pastures (Thomas, 1995). Moreover, Cratylia might be also used for recovery of degraded areas (Marques et al., 2014). 
The species is able to carry out symbiosis with nitrogen fixing bacteria (Castillo et al., 2007), a characteristic that merits special attention. The biological nitrogen fixation in the tropics is a key process for agricultural sustainability (Hungria and Vargas, 2000) and inoculation as one of the most important sustainable practices for agriculture (Souza et al., 2015).

Argel and Lascano (2002) highlighted that C. argentea responds to inoculation of Rhizobium strains from cowpea (Vigna ungüiculata (L.) Walp.) common in the tropical soils. It is estimated that nodulation occurs as of 100 days after sowing (Oliveira et al., 1998); nevertheless, studies that precisely define this period were not found.

In Brazil, there are no cultivars and inoculants registered with the Ministry of Agriculture (Ministério da Agricultura, Pecuária e Abastecimento- MAPA) for C. argentea. In addition, there are few scientific studies regarding aspects related to biological nitrogen fixation in the species, which denotes that the use of inoculants for $C$. argentea is not very adopted in the world. In this context, considering the importance and potential of this culture as a better option for livestock feed and green manure and for recovery of degraded areas, the aim of this study was to evaluate the response of $C$. argentea to inoculation with rhizobium strains.

\section{Results}

\section{Efficiency of inoculants}

The $C$. argentea plants inoculated with SEMIA 6464, SEMIA 6462, CR 33, CR 42, and CPAC-B10 did not exhibit nodulation and did not differ from the plants of the control treatment (NI) (Table 1).

In contrast, the plants inoculated with CR 52 exhibited expressive nodulation, differing from the plants of the treatment without inoculant (NI) (Table 1 and Figure 1). Inoculation with CR52 increased the $\mathrm{N}$ and crude protein contents of the shoots compared to plants of the control treatment (NI); however, they were less than in the treatment with nitrogen fertilization (WN). The nodular efficiency calculated was 0.189 , and the relative efficiency was $66.14 \%$.

Inoculation of $C$. argentea with SEMIA 6464, SEMIA 6462, CR 33, CR 42, and CEPAC - B10 did not change the height, number of leaves, and number of nodes of the plant after 145 days of cultivation in relation to the $\mathrm{NI}$ control. Nevertheless, nitrogen fertilization (WN) led to greater values of these characteristics in relation to the treatments with or without inoculation (Table 2).In the same way observed for shoot dry matter (SDM), inoculation with CR 52 proved to be efficient for growth of $C$. argentea, which exhibited values for height, number of leaves, and number of nodes of the plant after 145 days of cultivation similar to the treatment with application of $\mathrm{N}$ (WN) (Table 2).

\section{Response to inoculation}

It was possible to observe the effect of nodulation at 85 days after planting where the differences for the mean values of the "number of leaves" variable were detected between the treatments with inoculant (WI) and without inoculant (NI). The mean values of the $\mathrm{WI}$ and $\mathrm{NI}$ treatments for the "number of nodes" and "plant height" variables exhibited significant differences as of 100 days after planting (Table 3 ).

\section{Discussion}

Among the six tested strains, nodulation was observed only when plants where inoculated with strain CR52. The results showed the difficulty of selecting strains that are efficient for some species of perennial leguminous plants, as reported by Kaiweiet al. (2013) for the species L. leucocephala.

The value of nodular efficiency was low in relation to the efficiency found in studies with $V$. unguiculata (Zilli et al. 2011), Trifolium resupinatumL. cv. Kyambro, Trifolium subterraneum L. cv.Woogenellup, and Lotus subbiflorusLag. cv. El Rincón (Krolow et al., 2004), studies evaluating this variable in $C$. argentea were not found. However, Lascano et al. (2002) report that $C$. argentea was able to form up to 24 nodules after 145 days when inoculated with Bradyrhizobium strains CIAT 3561 and 3564 in acid soils with high levels of aluminum. For L. leucocephala, which also is a perennial leguminous plant, Kadiata et al. (1993) observed that biomass yield, $\mathrm{N}$ accumulation, and $\mathrm{N}_{2}$ fixation increased between 4 and 12 months after planting, a situation that may be related to the low nodular efficiency found in $C$. argenteaat the beginning of its development.

The value of relative efficiency was satisfactory when compared to that found in strains for Glycine max (L.) Merr. (Ribeiro et al., 2015) and Vigna angularis (Willd.) Ohwiand $\mathrm{H}$. Ohashi (Delić et al., 2010), but reduced in relation to strains for Phaseolus lunatus L. (Antunes et al., 2011) and Cajanus cajan(L.) Huth (Rufini et al., 2014).

The nodulation effect appears late in $C$. argentea compared with other species with shorter cycles as $V$. unguiculata (Melo and Zilli, 2009; Rufini et al., 2014), P. lunatus (Antunes et al., 2011), G. $\max$ (Pereira et al., 2013; Ribeiro et al., 2015) and C. cajan (Rufini et al, 2014). However, the observed effect was similar to that obtained for L. leucocephala (Azad et al., 2013) that has arboreal habit.

In spite of having stood out in a protected environment, the inoculant CR 52 must be evaluated under different field conditions so as to identify its potential for agricultural use. Melo and Zilli (2009) showed that the interference of soil and climate factors reduced the nodulation of $V$. unguiculata plants grown in the field compared to those grown in a greenhouse. The success in nodulation of leguminous plants is a complex process that depends on different environmental factors, such as amount of available P (Abbasi et al., 2008), presence of other leguminous plants nearby (Nascimento et al., 2008), soil acidity (Meghvansi et al., 2005), interaction with microorganisms (Azcón-Aguilar and Barea, 2015), and water and heat stresses (Silva et al., 2012).

\section{Materials and Methods}

\section{Origin of strains}

The six rhizobia strains used in the study were supplied by Johanna Döbereiner Biological Resource Center (CRB-JD, Embrapa Agrobiologia, Seropédica, Rio de Janeiro, Brazil) in the form of peat-based inoculants. The inoculation treatments consisted of three strains isolated from $C$. argentea plants CR 33 (BR10243), Rhizobium sp., CR52 
Table 1. Shoot dry matter (SDM), number of nodules (NN), nodule dry matter (NDM), andN contents ( $N$ ) and crude protein contents (CP) of shoots, 150 days after planting, in three treatments: with inoculant and without nitrogen fertilization (WI), without inoculant and without nitrogen fertilization (NI), and without inoculant and with nitrogen fertilization (WN). SDM (g), NN (Un.), $\operatorname{NDM}(\mathrm{g}), \mathrm{N}\left(\mathrm{dag} \cdot \mathrm{Kg}^{-1}\right)$, and $\mathrm{CP}\left(\mathrm{dag} \cdot \mathrm{Kg}^{-1}\right)$.

\begin{tabular}{|c|c|c|c|c|c|c|}
\hline Inoculant & Treatment & SDM & $\mathrm{NN}$ & NDM & $\mathrm{N}$ & $\mathrm{CP}$ \\
\hline \multirow{4}{*}{ SEMIA 6464} & WI & $0.31 \mathrm{~b}$ & 0 & 0 & $1.36 \mathrm{~b}$ & $8.5 \mathrm{~b}$ \\
\hline & $\mathrm{NI}$ & $0.27 b$ & 0 & 0 & $1.24 \mathrm{~b}$ & $7.75 b$ \\
\hline & WN & $8.74 \mathrm{a}$ & 0 & 0 & $3.89 a$ & $24.31 \mathrm{a}$ \\
\hline & CV (\%) & 39.69 & 0 & 0 & 22.41 & 22.41 \\
\hline \multirow{4}{*}{ SEMIA 6462} & WI & $0.39 \mathrm{~b}$ & 0 & 0 & $1.43 \mathrm{~b}$ & $8.93 \mathrm{~b}$ \\
\hline & $\mathrm{NI}$ & $0.23 \mathrm{~b}$ & 0 & 0 & $1.32 \mathrm{~b}$ & $8.25 b$ \\
\hline & WN & $10.33 \mathrm{a}$ & 0 & 0 & $3.77 \mathrm{a}$ & $23.56 \mathrm{a}$ \\
\hline & CV (\%) & 61.84 & 0 & 0 & 25.82 & 25.82 \\
\hline \multirow{4}{*}{ CR 52} & WI & $7.64 \mathrm{a}$ & $237.6 \mathrm{a}$ & $0.808 \mathrm{a}$ & $2 \mathrm{~b}$ & $12.5 \mathrm{~b}$ \\
\hline & $\mathrm{NI}$ & $0.23 \mathrm{~b}$ & $\mathrm{Ob}$ & $0 \mathrm{~b}$ & $1.46 \mathrm{c}$ & $9.12 \mathrm{c}$ \\
\hline & WN & $11.55 \mathrm{a}$ & $\mathrm{Ob}$ & $0 \mathrm{~b}$ & $3.38 \mathrm{a}$ & $21.12 \mathrm{a}$ \\
\hline & CV (\%) & 45.72 & 55.26 & 39.12 & 7.14 & 7.14 \\
\hline \multirow{4}{*}{ CR 33} & WI & $0.45 \mathrm{~b}$ & 0 & 0 & $1.27 \mathrm{~b}$ & $7.93 \mathrm{~b}$ \\
\hline & $\mathrm{NI}$ & $0.28 b$ & 0 & 0 & $1.45 \mathrm{~b}$ & $9.06 \mathrm{~b}$ \\
\hline & WN & $13.74 \mathrm{a}$ & 0 & 0 & $2.97 \mathrm{a}$ & $18.56 \mathrm{a}$ \\
\hline & CV (\%) & 66.33 & 0 & 0 & 16.32 & 16.32 \\
\hline \multirow{4}{*}{ CR 42} & WI & $0.32 \mathrm{~b}$ & 0 & 0 & $1.42 \mathrm{~b}$ & $8.87 \mathrm{~b}$ \\
\hline & $\mathrm{NI}$ & $0.19 \mathrm{~b}$ & 0 & 0 & $1.43 \mathrm{~b}$ & $8.93 \mathrm{~b}$ \\
\hline & WN & $15.34 \mathrm{a}$ & 0 & 0 & $3.69 a$ & $23.06 \mathrm{a}$ \\
\hline & CV(\%) & 41.77 & 0 & 0 & 12.13 & 12.13 \\
\hline \multirow{4}{*}{$\mathrm{CPAC}-\mathrm{B} 10$} & WI & $0.28 \mathrm{~b}$ & 0 & 0 & $1.37 \mathrm{~b}$ & $8.56 \mathrm{~b}$ \\
\hline & $\mathrm{NI}$ & $0.22 \mathrm{~b}$ & 0 & 0 & $1.48 \mathrm{~b}$ & $9.25 \mathrm{~b}$ \\
\hline & WN & $12.09 \mathrm{a}$ & 0 & 0 & $3.07 \mathrm{a}$ & $19.18 \mathrm{a}$ \\
\hline & CV (\%) & 29.01 & 0 & 0 & 14.85 & 14.85 \\
\hline
\end{tabular}

Mean values followed by the same letter in the column do not differ statistically by the Tukey test $(p<0.05)$.

Table 2. Mean values of the variables of number of nodes, number of leaves, and height at 145 days after planting of the treatments: with inoculant and without nitrogen fertilization (WI), without inoculant and without nitrogen fertilization (NI), and without inoculant and with nitrogen fertilization (WN). Specifically for the WI treatments, inoculants were used containing the following strains: SEMIA 6464, SEMIA 6462, CR 33, CR 42, CR 52, and CEPAC - B10. Number of nodes (Un.), number of leaves (Un.) and height $(\mathrm{cm})$.

\begin{tabular}{|c|c|c|c|c|}
\hline Inoculant & Treatment & Number of nodes & Number of leaves & Height \\
\hline \multirow{4}{*}{ SEMIA 6464} & WI & $13.1725 \mathrm{~b}$ & $8.197 \mathrm{~b}$ & $1.08939 \mathrm{~b}$ \\
\hline & $\mathrm{NI}$ & $11.8138 \mathrm{~b}$ & 7.652 b & $1.05923 \mathrm{~b}$ \\
\hline & WN & $19.9784 \mathrm{a}$ & $18.723 \mathrm{a}$ & $1.67301 \mathrm{a}$ \\
\hline & CV (\%) & 10.50 & 19.12 & 7.74 \\
\hline \multirow{4}{*}{ SEMIA 6462} & WI & $12.8263 \mathrm{~b}$ & $8.130 \mathrm{~b}$ & $1.0708 \mathrm{~b}$ \\
\hline & $\mathrm{NI}$ & $11.7780 \mathrm{~b}$ & 9.4928 b & $0.9093 \mathrm{~b}$ \\
\hline & WN & $22.2889 \mathrm{a}$ & $21.7683 \mathrm{a}$ & $1.7356 \mathrm{a}$ \\
\hline & CV (\%) & 8.77 & 10.87 & 20.70 \\
\hline \multirow{4}{*}{ CR 33} & WI & $2.40 \mathrm{~b}$ & $1.8 \mathrm{~b}$ & $7.02 b$ \\
\hline & $\mathrm{NI}$ & $2.80 \mathrm{~b}$ & $2.00 \mathrm{~b}$ & $5.52 \mathrm{~b}$ \\
\hline & WN & $12.60 \mathrm{a}$ & $12.20 \mathrm{a}$ & $63.03 \mathrm{a}$ \\
\hline & CV (\%) & 25.37 & 25.15 & 44.69 \\
\hline \multirow{4}{*}{ CPAC B10 } & WI & $2.20 \mathrm{~b}$ & $1.80 \mathrm{~b}$ & $5.20 \mathrm{~b}$ \\
\hline & $\mathrm{NI}$ & $1.50 \mathrm{~b}$ & $0.75 \mathrm{~b}$ & $4.35 \mathrm{~b}$ \\
\hline & WN & $12.40 \mathrm{a}$ & $11.80 \mathrm{a}$ & $66.54 \mathrm{a}$ \\
\hline & CV (\%) & 22.17 & 22.86 & 39.89 \\
\hline \multirow{4}{*}{ CR 42} & WI & $3.20 \mathrm{~b}$ & $2.00 \mathrm{~b}$ & $6.56 \mathrm{~b}$ \\
\hline & $\mathrm{NI}$ & $2.40 \mathrm{~b}$ & $2.00 \mathrm{~b}$ & 5.42 b \\
\hline & WN & $15.00 \mathrm{a}$ & $14.40 \mathrm{a}$ & $76.54 \mathrm{a}$ \\
\hline & CV (\%) & 21.44 & 15.75 & 47.18 \\
\hline \multirow{4}{*}{ CR 52} & WI & $8.60 \mathrm{a}$ & $8.60 \mathrm{a}$ & $32.54 \mathrm{~b}$ \\
\hline & $\mathrm{NI}$ & $2.60 \mathrm{~b}$ & $2.00 \mathrm{~b}$ & $5.50 \mathrm{c}$ \\
\hline & WN & $12.00 \mathrm{a}$ & $11.00 \mathrm{a}$ & $62.42 \mathrm{a}$ \\
\hline & CV (\%) & 32.28 & 36.57 & 31.55 \\
\hline
\end{tabular}

Mean values followed by the same letter in the column do not differ statistically by the Tukey test $(p<0.05)$. 


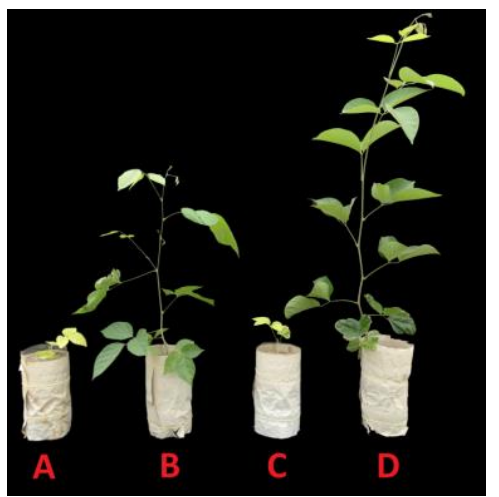

Fig 1. C. argentea plants at 150 days after planting:(a) plant with inoculant CR 33, which represents the other treatments with inoculants that did not form nodules; (b) plant with inoculant containing the strain CR 52; (c) plant without $\mathrm{N}$ fertilization and without inoculant; (d) plant without inoculant and with $\mathrm{N}$ fertilization.

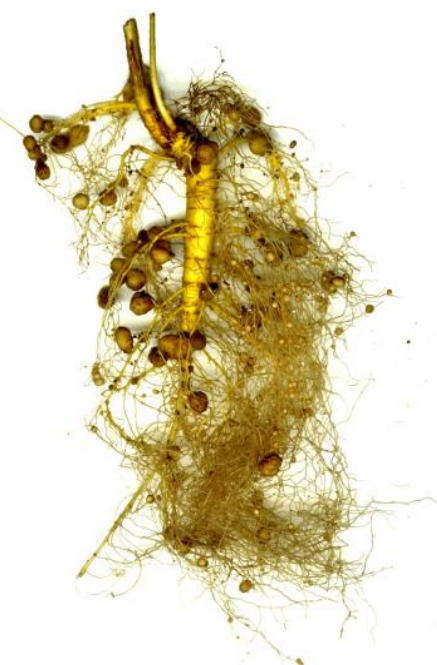

Fig 2. C. argentea root inoculated with CR 52, 150 days after planting. Presence of nodules and good development of the primary root.

Table 3. Mean values of the variables of number of nodes, number of leaves, and height, in the period from 70 to 145 days after planting for the treatments: with inoculant and without nitrogen fertilization (WI), without inoculant and without nitrogen fertilization (NI), and without inoculant and with nitrogen fertilization (WN). Specifically for the WI treatment, the inoculant containing the strain CR 52 was used. Number of nodes (Un.), number of leaves (Un.), and height (cm).

\begin{tabular}{|c|c|c|c|c|c|c|}
\hline \multirow{2}{*}{ Cond/time } & \multicolumn{6}{|c|}{ Number of nodes } \\
\hline & 70 & 85 & 100 & 115 & 130 & 145 \\
\hline WI & $1.57 \mathrm{bD}$ & $3.2 \mathrm{bC}$ & $3.8 \mathrm{bC}$ & $5 b B C$ & $6.2 \mathrm{bB}$ & $8.6 \mathrm{aA}$ \\
\hline $\mathrm{NI}$ & $1 \mathrm{bB}$ & $1.2 \mathrm{bB}$ & $1.4 \mathrm{cB}$ & $1.6 \mathrm{cB}$ & $2.4 \mathrm{cA}$ & $2.6 \mathrm{bA}$ \\
\hline WN & $5.25 \mathrm{aC}$ & $6 \mathrm{aC}$ & $6.75 \mathrm{aBC}$ & $8.75 a A B C$ & $11 \mathrm{aAB}$ & $12 \mathrm{aA}$ \\
\hline \multirow{2}{*}{ Cond/time } & \multicolumn{6}{|c|}{ Number of leaves } \\
\hline & 70 & 85 & 100 & 115 & 130 & 145 \\
\hline WI & $1.57 \mathrm{bE}$ & $3.2 \mathrm{bD}$ & $3.8 \mathrm{bCD}$ & $5 b B C$ & $6.2 \mathrm{bB}$ & $8.6 \mathrm{aA}$ \\
\hline $\mathrm{NI}$ & $1 \mathrm{bB}$ & $1.2 \mathrm{cB}$ & $1.2 \mathrm{cB}$ & $1.4 \mathrm{cB}$ & $2 c A$ & $2 \mathrm{bA}$ \\
\hline WN & $5 \mathrm{aA}$ & $6.75 \mathrm{aA}$ & $6.75 \mathrm{aA}$ & $8.5 \mathrm{aA}$ & $10.25 \mathrm{aA}$ & $11 \mathrm{aA}$ \\
\hline \multirow{2}{*}{ Cond/time } & \multicolumn{6}{|c|}{ Plant height } \\
\hline & 70 & 85 & 100 & 115 & 130 & 145 \\
\hline WI & $6.04 \mathrm{bE}$ & $9.3 b D$ & $12.12 \mathrm{bCD}$ & $17.08 \mathrm{bBC}$ & $23.72 \mathrm{bB}$ & $32.54 \mathrm{bA}$ \\
\hline $\mathrm{NI}$ & $4.43 \mathrm{bA}$ & $4.58 \mathrm{bA}$ & $4.6 \mathrm{cA}$ & $4.72 \mathrm{cA}$ & $5.26 \mathrm{cA}$ & $5.5 \mathrm{cA}$ \\
\hline WN & 13.72aD & 21.9aCD & $24.87 \mathrm{aCD}$ & $38.17 a \mathrm{BC}$ & $48.77 a A B$ & $62.42 \mathrm{aA}$ \\
\hline
\end{tabular}

Mean values followed by equal lowercase letters in the column and mean values followed by equal uppercase letters in the line do not differ among themselves at $5 \%$ probability by the Tukey test. 
(BR10257) Bradyrhizobium sp. and CR42 (BR10244) Bradyrhizobium sp., two strains officially recommended for Vigna unguiculata (L.) Walp. (cowpea) inoculant production in Brazil (Brasil, 2011) SEMIA 6464 (BR3262) Bradyrhizobium sp. and SEMIA 6462 (BR3267) Bradyrhizobium sp. and a strain recommended for various green manure crops CPACB10 (BR10228) Bradyrhizobium sp.

\section{Greenhouse experiment for symbiotic effectiveness}

The experiments were conducted in a greenhouse for 150 days. C. argentea seeds underwent disinfection for 10 minutes in sodium hypochlorite $(5 \%)$ and, after that, 10 successive washings with sterile distilled water. They were pre-germinated in for a week in a germination chamber regulated to $25^{\circ} \mathrm{C}$ and then sown in Leonard pots (Santos et al., 2009) with a mixture of sterilized sand and vermiculite (2:1; v:v) substrate, and every week they received $0.5 \mathrm{~L}$ of Norris nutrient solution (Norris and Date, 1976) and complementary watering with distilled autoclaved water when necessary. Treatments consisted of $1 \mathrm{~mL}$ (approximately $1.2 \times 10^{6} \mathrm{CFU}$ seed $^{-1}$ ) of inoculant from the six bacterial strains without nitrogen fertilization (WI), without inoculant and without nitrogen fertilization (NI) and without inoculant and with nitrogen fertilization, consisting of $0.10 \mathrm{~g}$ of ammonium nitrate was applied in the first two weeks, and $0.20 \mathrm{~g}$ in the subsequent weeks (WN) with five replicates.

The trials with the inoculants SEMIA 6464 and SEMIA 6462 were carried out in a greenhouse without climate control, with minimum temperature of $20^{\circ} \mathrm{C}$ and maximum of $34^{\circ} \mathrm{C}$, from March to August 2014. The trials with the other inoculants were carried out in a climate-controlled greenhouse regulated at a temperature of $25^{\circ} \mathrm{C}$, from July to December 2014.

At 150 days after planting, C. argentea plants were collected and separated into roots and shoots. Nodules were counted, and then nodules and shoots were dried in a forced air circulation laboratory oven $(60$ 으 for $72 \mathrm{~h}$ ). After that, shoot dry matter, nodule dry matter, and the total nitrogen and crude protein contents for the shoots of each treatment were determined. Total $\mathrm{N}$ was determined by titration after digestion by the Kjeldahl method, and crude protein content was calculated using the conversion factor of 6.25 , as described by Galvani and Gaertner (2006). Nodular efficiency was calculated following the formula proposed by Brasil (2011) and relative efficiency (RE) through the formula: RE = (dry matter of the inoculated treatment X 100) / dry matter of the treatment with $\mathrm{N}$. The effect of nodulation as a function of time was observed from 70 to 145 days after planting. The following parameters were determined every two weeks for all the treatments: plant height $\left(\mathrm{cm}\right.$. plant $\left.{ }^{-1}\right)$ and number of nodes and number of leaves. Plant height was measured as of the height of the cotyledonary node.

\section{Experimental design and statistical analysis}

Randomized experimental design was adopted, and the trials were conducted separately for each inoculant so as to avoid contamination from the pots containing the inoculated plants. The data of the variables evaluated were subjected to analysis of variance. After that, the Tukey test at 5\% probability was applied for comparison between the means of the treatments. For evaluation of nodulation effect as a function of time, analysis of split-plots in time was adopted.

\section{Conclusion}

Among the six inoculants used, only the CR 52 was efficient in relation to nodulation, a condition that shows high plantbacterium specificity. The inoculant containing the strain CR 52 was effective in increasing $\mathrm{N}$ acquisition by $\mathrm{C}$. argentea and in promoting greater plant growth. It was possible to observe the effect of nodulation in plants inoculated as of 85 days after planting. This effect appears late in the evaluated specie when compared with shorter cycle species with faster development. The nodulation occurs in the roots of $C$. argentea inoculated grown in a sterilized sand and vermiculite $(2: 1 ; \mathrm{v}: \mathrm{v})$ substrate in a protected environment. Therefore, the tests with $C$. argentea inoculated with CR-52 cultivated in different field conditions shall be done to assess this inoculant efficiency in adverse environments. This paper shows that is difficult to select strains for the studied specie. This shows that it is needed more research on the selection of new strains in different environments mainly when considering the high phenotypic plasticity of the $C$. argentea that occurs in several biomes.

\section{Acknowledgments}

Our thanks to Dr. Ivanildo Marriel, Dr. Walter Matrangolo, Fundação de Amparo à Pesquisa do Estado do Acre (FAPAC), Fundação de Amparo a Pesquisa de Minas Gerais (FAPEMIG), Coordenação de Aperfeiçoamento de Pessoal de Nível Superior (CAPES), Embrapa Agrobiologia, Embrapa Milho e Sorgo, Universidade Federal de Viçosa (UFV), Universidade Federal do Acre (UFAC), programa de pós graduação em fisiologia vegetal da UFV and Grupo de Estudos em Produção e Tecnologia de Sementes (GSEM - UFV).

\section{References}

Abbasi MK,Majeed A, Sadiq Aand Khan SR (2008) Application of Bradyrhizobium japonicum and phosphorus fertilization improved growth, yield and nodulation of soybean in the sub-humid hilly region of Azad Jammu and Kashmir, Pakistan. Plant Prod Sci. 11(3):368-376.

Alpala JR, Grisales SO, Franco LH, Peters M and Ramírez G (2010) Sowing systems of Cratylia argentea cultivar veranera in two localities of the valledelrío Cauca, Colombia. Acta Agron. 59 (4): 429-434.

Antunes JEL, Gomes RLF, Lopes AC de A, Araújo ASF de, Lyra $M$ do CCP de andFigueiredo $M$ do VB (2011) Eficiência simbiótica de isolados de rizóbio noduladores de feijãofava (Phaseolus lunatus L.). Rev Bras Cienc Solo. 35: 751757.

Argel PJ and Lascano CE (2002) Cratylia argentea: una nueva leguminosa arbustiva para suelos ácidos em zonas subhúmedas tropicales. Pasturas tropicales. 20(1): 37 - 43

Argel PJ, Lobo Di Palma M, Romero F, González J, Lascano CE, Kerridge PC and Holmann F (2000) Silage of Cratylia argentea as dry-season feeding alternative in Costa Rica.In: FAO electronic conference on tropical silage. FAO, Rome.

Azcón-Aguilar C and Barea JM (2015) Nutrient cycling in the mycorrhizosphere. J Soil Sci Plant Nut. 15(2): 372-396. 
Azad S, Mondol S, Matin A (2013) Functional relationships of nodulation response and biomass production at nursery stages of two fast-growing, leguminous multipurpose tree species in Bangladesh: Albizia saman andLeucaena leucocephala. For Sci Pract. 15 (4) : 274-285

Brasil. Instrução normativa $\mathrm{N}^{\circ} 13$, de 24 de março de (2011) Protocolo oficial para avaliação da viabilidade e eficiência agronômica de cepas, inoculantes e tecnologias relacionados ao processo de fixação biológica do nitrogênio em leguminosas. Diário Oficial da República Federativa do Brasil, Poder Executivo, Brasília, DF, 25 mar. 2011 Seção 1.

Castillo AR, Barbosa OP, Arango JLP, Cerinza OJ, Pinzón SM, Correal WA, Barreto AR (2007) Estabelecimiento, manejo y uso de la leguminosa arbustiva forrajera Cratylia argentea cv Veranera em el Piedeminte Lianero. Corporación Colombiana de Investigación Agropecuaria, Villavicencio. 24.

Cook BG, Pengelly BC, Brown SD, Donnelly JL, Eagles DA, Franco MA, Hanson J, Mullen BF, Partridge IJ, Peters $M$ and Schlteze-Kraft R (2005) Tropical Forages: an interactive selection tool. Brisbane: CSIRO, DPlandF, CIAT and ILRI. Availableat: < http://www.tropicalforages.info/ > Accessed on: 28 Oct. 2014

Delić $D$, Stajković $O$, Rasulić $N$, Kuzmanović $D$, Jošić $D$, Miličić, $B$ (2010) Nodulation and $N_{2}$ fixation effectiveness of Bradyrhizobium strains in symbiosis with Adzuki Bean, Vigna angularis. Braz Arch Biol Techn. 53 (2):293-299.

Galvani F and Gaertner E (2006) Adequação da metodologia Kjeldahl para determinação de nitrogênio total e proteína bruta.Embrapa Pantanal, Corumbá. 8.

Hungria M, Vargas MAT (2000) Environmental factors affecting $\mathrm{N}_{2}$ fixation in grain legumes in the tropics, with an emphasis on Brazil. Field Crop Res. 65: 151-164.

Kadiata BD, Mulongoy K, Isirimah NO (1995) Dynamics of nodulation, nitrogen fixation, nitrogen use and biomass yield over time in pot-grown Leucaena leucocephala (Lam.) de Wit. Biol Fert Soils. 20, 163-168

Kaiwei X,Penttinen P, Chen Y, Qiang C, Xiaoping Z (2013) Symbiotic efficiency and phylogeny of the rhizobia isolated from Leucaena leucocephala in arid-hot river valley area in Panxi, Sichuan, China. Appl Microbiol Biot. 97 (2): 783-93.

Krolow RH,Mistura C, Coelho RW, Siewerdt LandZonta ÉP (2004) Efeito do fósforo e do potássiosobre o desenvolvimento e a nodulação de trêsleguminosasanuais de estaçãofria. Rev Bras Zootecn. 33 (6): 2224-2230.

Lascano C, Rincón A,Plazas C, Avila P, Bueno G and Argel PJ (2002) Cultivar Veranera (Cratylia argentea (Desvaux) 0. Kuntze) - Leguminosa arbustiva de usos múltiplos para zonas com períodos prolongados de sequía em Colombia. International Center for Tropical Agriculture - CIAT, Cali. 24.

Marques TED, Baêta HE, Leite MGP, Martins SV and Kozovits AR (2014) Growth of cerrado native species and of Vetiveriazizanioides in colluvium of gullies. Cienc Florest. 24(4), 843-856.

Meghvansi MK, Prasad Kand Mahna SK (2005) Identification of $\mathrm{pH}$ tolerant Bradyrhizobium japonicum strains and their symbiotic effectiveness in soybean [Glycine $\max$ (L.) Merr.]in low nutrient soil. Afr J Biotechnol. 4 (7): 663-666

Melo SR de and Zilli JÉ (2009) Fixaçãobiológica de nitrogênio em cultivares de feijao-caupi recomendadas para o Estado de Roraima.Pesqui Agropecu Bras. 44 (9): 1177-1183.
Nascimento CS do, Lira Junior MA, Stamford NP, Freire MBGS and Sousa CA (2008) Nodulação e produção do caupi (Vigna unguiculata L. Walp) sob efeito de plantas de cobertura e inoculação. Rev Bras. Cienc Solo. 32:579-587

Norris DO and Date RA (1976) Legume bacteriology. In: Shaw, NJL and Bryan WW. Tropical pasture research, principles and methods. Hurley. p. $234-274$.

Oliveira FL. de, Pitard RM and Souto SM (1998) Seleção de estirpes de rizóbio para leguminosas Arachis pintoi e Cratylia argentea. EmbrapaAgrobiologia, Seropédica.21.

Pereira MG, Santos CERS, Freitas ADS de, Stamford NP, Rocha GSDC da and Barvosa AT (2013) Interações entre fungos micorrízicos arbusculares, rizóbio e actinomicetos na rizosfera de soja. Rev Bras Eng Agr Amb. 17 (12):12491256.

Queiroz LP. de (1991) O gênero Cratylia Martius ex Bentham (LEGUMINOSAE: PAPILIONOIDEAE: PHASEOLEAE): revisão taxonômica e aspectos biológicos. Unicamp, Campinas. 129.

Reyes SN, Ledin S and Ledin I (2007) Biomass production and nutritive composition of Cratylia argentea under different planting densities and harvest intervals. J Sustain Agr. 29(4): 5-22.

Ribeiro PR de A, Santos JV dos, Costa, EM da, Lebbe L, Assis ES, Louzada MO, Guimarães AA, Willems A, Moreira FM de $S$ (2015) Symbiotic efficiency and genetic diversity of soybean bradyrhizobia in Brazilian soils. Agr Ecosyst Environ. 212: 85-93

Rufini M, Silva MAP da, Ferreira PAA, Cassetari A de $S$, Soares BLS, Andrade MJB de and Moreira FM de S (2014) Symbiotic efficiency and identification of rhizobia that nodulate cowpea in a Rhodic Eutrudox. Biol Fert Soils. 50:115-122

Rufini $M$, Oliveira D de $P$, Trochmann A, Soares BL, Andrade MJB de and Moreira FM de S (2014) Estirpes de Bradyrhizobium em simbiose com guandu-anão em casa de vegetação e no campo. Pesqui Agropecu Bras Brasília. 49 (3): 197-206.

Santos CE de RS, Bezerra R de V, Freitas ADS de, Seido SL, Martins LMV, Rumjanek NG and Xavier GR (2009) Modificações de vasos Leonard com garrafas descartáveis tipo Pet. Embrapa Agrobiologia, Seropédica.4.

Sarria PI and Martens SD (2013) The voluntary intake in growing pigs of four ensiled forage species. Agr Food Sci. 22:201-206.

Silva HAP da, Galisa P de S, Oliveira RS da S, Vidal MS. and Araujo JLS (2012) Expressão gênica induzida por estresses abióticos em nódulos de feijao-caupi. Pesqui Agropecu Bras Brasília. 47(6): 797-807.

Souza R de, Ambrosini A and Passaglia LMP (2015) Plant growth-promoting bacteria as inoculants in agricultural soils. Genet Mol Biol. 38(4):401-419.

Thomas RJ (1995) Role of legumes in providing $\mathrm{N}$ for sustainable tropical pasture systems. Plant Soil. 174: 103118.

Zilli JE, Silva Neto ML da, França Júnior I, Perin L and Melo AR de (2011) Resposta do feijão-caupi à inoculação com estirpes de Bradyrhizobium recomendadas para soja. Rev Bras Cienc Solo. 35:739-742 